\title{
Production of ornamental sunflower irrigated with oilfield produced water in the Brazilian semiarid region
}

\author{
Olmar Baller Weber(1), Lindbergue Araújo Crisostomo(1), Fabio Rodrigues de Miranda(1), \\ Adervan Fernandes Sousa ${ }^{(2)}$, Antônio Lindemberg Martins Mesquita ${ }^{(1)}$ and José Ednilson de Oliveira Cabral ${ }^{(1)}$ \\ (1)Embrapa Agroindústria Tropical, Rua Dra. Sara Mesquita, oo 2.270, Planalto do Pici, CEP 60511-110 Fortaleza, CE, Brazil. E-mail: \\ olmar.weber@embrapa.br, lindbergue.crisostomo@embrapa.br, fabio.miranda@embrapa.br, lindemberg.mesquita@embrapa.br, \\ ednilson.cabral@embrapa.br (2)Universidade Estadual do Ceará, Faculdade de Educação de Crateús, Rua Dr. José Sabóia Livereiro, \\ № 1.489, CEP 63700-000 Crateús, CE, Brazil. E-mail: adervansousa@yahoo.com.br
}

\begin{abstract}
The objective of this work was to evaluate the effects of irrigation with oilfield produced water on the concentration of some soil nutrients, as well as on the performance and concentration of nutrients in the roots and on aerial parts of the ornamental sunflower 'Sunbright' (Helianthus annuus), and to define the operating costs for the production of floral stems under an irrigated system. 'Sunbright' sunflower plants were cultivated in a Typic Quartzipsamment in the state of Ceará, Brazil, and subjected to drip irrigation treatments with oilfield produced water treated by filtration (PWF), or by reverse osmosis (PWO), besides a control treatment with groundwater (GW) from the Açu aquifer. The study was carried out for three successive production cycles. Irrigation with PWF modifies the concentration of exchangeable salts in the soil, increasing $\mathrm{Na}^{+}$in the shallow layers, affecting the vegetative growth and the nutrient accumulation in the roots and shoots, in such a way that brackish water may impact operating costs and revenues in the production of floral stems. PWO has a minor effect on soil nutrients and it is not able to modify the agronomic performance of the ornamental sunflowers, in comparison with irrigation with GW. The cost-benefit ratio was positive with all types of water in the following order: GW $>$ PWF $>$ PWO.
\end{abstract}

Index terms: Helianthus annuиs, cut flower, irrigation, resource use efficiency, wastewater reuse.

\section{Produção de girassol ornamental irrigado com água produzida de petróleo na região do Semiárido brasileiro}

\begin{abstract}
Resumo - O objetivo deste trabalho foi avaliar os efeitos da irrigação com água produzida de campos de petróleo sobre a concentração de alguns nutrientes do solo, assim como sobre o desempenho e a concentração de nutrientes nas raízes e nas partes aéreas do girassol (Helianthus annuus) ornamental 'Sunbright', e definir os custos operacionais para a produção de hastes florais em um sistema irrigado. As plantas de girassol 'Sunbright' foram cultivadas em um Neossolo Quartzarênico no Estado do Ceará, e submetidas a tratamentos de irrigação por gotejamento, com água produzida de petróleo tratada por filtração (PWF) e por osmose inversa (PWO), além de um tratamento-controle com água subterrânea $(\mathrm{GW})$ do aquífero Açu. O estudo foi realizado por três ciclos de produção sucessivos. A irrigação com PWF modifica a concentração de sais trocáveis no solo, ao aumentar o $\mathrm{Na}^{+}$ nas camadas superficiais, o que afeta o crescimento vegetativo e o acúmulo de nutrientes nas raízes e nas partes aéreas das plantas, de modo que a água salobra pode impactar os custos operacionais e as receitas na produção de hastes florais. PWO tem um efeito menor em nutrientes do solo e não é capaz de modificar o desempenho agronômico dos girassóis ornamentais, em comparação à irrigação com GW. A relação custo-benefício foi positiva com todos os tipos de água, na seguinte ordem: GW $>$ PWF $>$ PWO.
\end{abstract}

Termos para indexação: Helianthus annuus, flor de corte, irrigação, uso eficiente de recurso, reuso de água residuária.

\section{Introduction}

Brazil has a large supply of fresh water, but most of the reserves are concentrated in the Amazon region, while other regions bordering the Atlantic Ocean, especially the Northeast, have a low availability of fresh water (Bressiani et al., 2015). Water availability and management in the semiarid region frequently cause conflicts of interest with regard to drinking water between users of urban centers and rural areas, which has already been highlighted in the microregion of Baixo Jaguaribe, in the state of Ceará (Pereira \& Cuellar, 2015). 
The agricultural sector consumes about $70 \%$ of the fresh water (Siebert et al., 2010); and as to water scarcity, different water sources for the rural environment should be considered. Globally, groundwater used in agriculture represented $38 \%$ in 2010 , but only $18 \%$ in Brazil (Siebert et al., 2010). Wastewater obtained from industrial processes can also be used for irrigation (Oliveira et al., 2016) when safety is guaranteed for its organic constituents, and when there is chemical safety for mining organic constituents and minerals.

The Northeast region, in turn, has some onshore basins with hundreds of oilfields, from which about 44 million barrels of oil are extracted annually (ANP, 2016), together with connate water that is trapped in the rocky cracks. This is known as 'produced water' and represents the main residue from oil exploration. That wastewater is equivalent to three out of four liquid volumes extracted from oil wells (Munirasu et al., 2016). In some productive areas of the Northeast, however, the produced water yield reaches $95 \%$ of the total liquid extracted (Melo et al., 2010).

The problem is that produced water contains various organic and mineral constituents, and it may also contain toxic metals (Igunnu \& Chen, 2014), which leads to recommendations that produced water should undergo treatment. In the oilfield Belém farm of Petrobras, located in the Potiguar basin that covers territorial parts of Ceará and Rio Grande do Norte states, produced water undergoes filtration and treatment process by reverse osmosis (Melo et al., 2010). After those treatments, produced water showed no risk as to its toxic metals (Sousa et al., 2016) and aromatic and polyaromatic hydrocarbons (Crisostomo et al., 2016).

When adequately treated, produced water can become an alternative to irrigate crops whose products are not intended directly for human consumption. Sousa et al. (2016) tested produced water in the irrigation of sunflower plants (Helianthus annuus L.) 'BRS 321' for oil production, and observed that produced water obtained by simple filtration was brackish and affected plant nutrition. In contrast, produced water treated by reverse osmosis did not affect the growth of those sunflowers. However, for the irrigation of other cultivars, these types of water may not be suitable. Both types of oilfield produced water affected, in the short term, the activity of soil microbes (Lopes et al., 2014). The negative effect of produced water treated by reverse osmosis may be due to the presence of residual glutaraldehyde (Lopes et al., 2014), which is used in the wastewater treatment process (Melo et al., 2010).

Irrigation with moderate salinity water has been tested in tolerant species, and sunflowers can be grown successfully in agricultural soils where the electrical conductivity reaches $4.8 \mathrm{dS} \mathrm{m}^{-1}$ (Francois, 1996). In turn, ornamental sunflower crops of 'Moonbright' and 'Sunbeam' tolerate water with up to $10.9 \mathrm{dS} \mathrm{m}^{-1}$ conductivity (Grieve \& Poss, 2010). Furthermore, Maciel et al. (2012) observed the same commercial value for stems of 'Red Sun' sunflower grown in hydroponic solution up to $16.36 \mathrm{dS} \mathrm{m}^{-1}$. This fact led to the idea of carrying out field tests with the use of brackish water in the production of cut flowers.

Floriculture is distinguished by its economic and social importance in Brazil (Silva et al., 2015), and there is also a demand in the domestic market for flowers and ornamental plants (Junqueira \& Peetz, 2014). This fact reinforces the idea of testing ornamental sunflower under irrigation, in the field, with wastewater from the petroleum industry, among other water sources available in the Brazilian Semiarid Region.

The objective of this work was to evaluate the effects of irrigation with two types of oilfield produced water on the concentration of some soil nutrients, as well as to estimate the performance and concentration of nutrients in the roots and aerial parts of the ornamental sunflower 'Sunbright', besides the operating costs of the production of floral stems in an irrigated system.

\section{Materials and Methods}

The experiment with ornamental sunflower hybrid F1 'Sunbright' was carried out at Petrobras Belém farm (FZB) in the municipality of Aracati, in the state of Ceará (CE), Brazil, at $4^{\circ} 44^{\prime} 46^{\prime \prime} \mathrm{S}, 37^{\circ} 32^{\prime} 18^{\prime \prime} \mathrm{W}$. The area is $6 \mathrm{~km}$ from the Petrobras Operating Unit in the municipality of Icapuí, CE, and it is just over 11 $\mathrm{km}$ from the Atlantic coast. The soil was classified as a Typic Quartzipsamment, with a sandy texture (sand ranging from 946 to $948 \mathrm{~g} \mathrm{~kg}^{-1}$ ), according to Crisostomo et al. (2016). Some climatic conditions, recorded in an automated weather station, were relatively uniform for the maximum $\left(33.2 \pm 0.3^{\circ} \mathrm{C}\right)$ and minimum $\left(22.7 \pm 0.5^{\circ} \mathrm{C}\right)$ air temperatures, relative air humidity $(72.4 \pm 4.0 \%)$, solar radiation $\left(19.4 \pm 1.6 \mathrm{MJ} \mathrm{m}^{-2}\right.$ per day), and evapotranspiration $(4.8 \pm 0.6 \mathrm{~mm}$ per 
day), during the three successive cycles of ornamental sunflower production, which is similar to that described for the sunflower crop for oil production (Crisostomo et al., 2016). However, there was a considerable variation in rainfall, since no rain event was noted in the first cycle and, during the second (April-June 2013) and third cycles (July-October 2013), $145 \mathrm{~mm}$ and $0.8 \mathrm{~mm}$ were recorded, respectively. It is well known that the poor distribution of rain during the year is typical for the tropical semiarid climate, according to the classification of Köppen-Geiger.

In a 3,600 $\mathrm{m}^{2}$ total area of, three irrigation treatments were set up, as follows: produced water treated by simple filtration (PWF), produced water treated by reverse osmosis (PWO), plus a groundwater control (GW) collected from wells, at $240 \mathrm{~m}$ soil depth, from the aquifer Açu. Water used in the irrigation system was supplied by FZB from its treatment plant (Melo et al., 2010). The first wastewater (PWF) was passed through sand-filled filters and cation exchange units; PWO was also subjected to a later stage, to reverse osmosis treatment, as previously reported by Lopes et al. (2014) and Sousa et al. (2016). The irrigation treatments with three replicates of $400 \mathrm{~m}^{2}$ each were randomly distributed in a complete block design in the field.

The ornamental sunflower assay was conducted for three consecutive production cycles, from July 2012 to October 2013. During that period, 17 samples of each type of water were collected at the entrance of the field, where pumped water was withdrawn for physicochemical and chemical characterization (Table 1), following standard methods (Eaton \& Franson, 2005). Based on the concentration of $\mathrm{Na}^{+}$, there would be severe restrictions on the use of PWF for crop irrigation, and a median restriction on the use of PWO and GW, as proposed by Ayers \& Westcot (1985). However, none of the three types of water showed toxic hydrocarbons (Crisostomo et al., 2016), and none showed levels of toxic metals (Sousa et al., 2016), which indicates more safety for water management in the field.

The preparation of the soil consisted of harrowing and opening furrows up to $30 \mathrm{~cm}$ depth, with one meter kept between the grooves. As a foundation fertilization, we applied the Polefértil organic compost (75 Mg ha $\left.{ }^{-1}\right)$, whose composition indicated $\left(\mathrm{kg}^{-1}\right.$ on a dry basis): $7.3 \mathrm{~g} \mathrm{~N} ; 71.3 \mathrm{~g} \mathrm{P} ; 73.6 \mathrm{~g} \mathrm{~K} ; 179.2 \mathrm{~g} \mathrm{Ca}$;
$22.6 \mathrm{~g} \mathrm{Mg} ; 22.5 \mathrm{~g} \mathrm{Na} ; 2.76 \mathrm{~g} \mathrm{Fe} ; 0.18 \mathrm{~g} \mathrm{Mn}$; and $0.14 \mathrm{~g}$ $\mathrm{Zn}$. For subsequent crops ( $2^{\text {nd }}$ and $3^{\text {rd }}$ cycles $)$, reduced dosages of that compost $\left(25 \mathrm{Mg} \mathrm{ha}^{-1}\right)$ were used, and the fertilizer was always incorporated into the soil. Such organic fertilizations were supplemented with urea (20 kg N ha-1), single superphosphate (80 kg $\left.\mathrm{P}_{2} \mathrm{O}_{5} \mathrm{ha}^{-1}\right)$, and potassium chloride $\left(40 \mathrm{~kg} \mathrm{~K}_{2} \mathrm{O} \mathrm{ha}{ }^{-1}\right)$, following the recommendations by Ambrosano et al. (1997), for the cultivation of sunflowers for oil in the São Paulo state. The NPK requirements of ornamental sunflower were still unknown for the semiarid region.

Sunflower plants were drip irrigated, using a drip line per row, with emitters whose flow was $1.0 \mathrm{~L} \mathrm{~h}^{-1}$, spaced $30 \mathrm{~cm}$ along the line. All plants were watered once a day, and for calculating the daily irrigation depths, the following parameters were taken into account: rainfall, crop evapotranspiration, and drainage losses $60 \mathrm{~cm}$ below the soil profile, measured with mini-lysimeter columns $(40 \mathrm{~cm}$ diameter by 60 $\mathrm{cm}$ depth) installed in the plots.

Before planting, seedlings had been prepared in the nursery. Seedlings were obtained from the germination of F1 hybrid 'Sunbright' in polystyrene trays with 200 cells, containing a mixture of washed sand, expanded commercial clay (particles with medium size), and organic compost from Polefértil (particles smaller than $2 \mathrm{~mm}$ ), using the 3:1:1 ratio (volume per volume). When seedlings grown in the trays reached about 8 to $10 \mathrm{~cm}$ height, they were transplanted into the field, in $1.0 \mathrm{~m}$ spacing between lines, and $50 \mathrm{~cm}$ between plants in the row for the first cycle. In subsequent cycles, spacing on the line was reduced, and $30 \mathrm{~cm}$ were left between plants in the row. In addition, during the production cycles, manual weeding was carried out, and no attack of pests and diseases was detected. This is possibly associated with the state of the fallow area before the cultivation of ornamental sunflower began.

By the harvesting time of ornamental sunflower stalks, in three cycles of production, composite soil samples were collected along the planting lines within the useful plots $\left(324 \mathrm{~m}^{2}\right)$. At each sampling point, five layers of soil (0-20, 20-40, 40-60, $60-80$, and $80-100 \mathrm{~cm}$ ) were extracted. These samples were dried in an oven with forced ventilation at a temperature regulated to $45^{\circ} \mathrm{C}$, passed through a sieve with a $2 \mathrm{~mm}$ mesh, and analyzed for $\mathrm{pH}$ in water (soil:water ratio 1:2.5), electrical conductivity, and levels of exchangeable cations (Claessen, 1997). The 
concentration of exchangeable cations $\left(\mathrm{Ca}^{2+}, \mathrm{Mg}^{2+}, \mathrm{K}^{+}\right.$, $\mathrm{Na}^{+}$) were obtained from the differences between the fractions of extractable elements of soil and fractions of soluble elements in a saturated paste with water, as recommended by Richards (1954). The percentage of sodium saturation (ESP) was obtained from the ratio of $\mathrm{Na}^{+}$and exchangeable cations $\left[\mathrm{Ca}^{2+}+\mathrm{Mg}^{2+}+\mathrm{K}^{+}\right.$ $\left.+\mathrm{Na}^{+}\left(\mathrm{Al}^{3+}+\mathrm{H}^{+}\right)\right]$of soil. The samples were further subjected to analysis of micronutrients $-\mathrm{Fe}, \mathrm{Mn}$, and $\mathrm{Zn}$, using the Mehlich-1 extractant $\left(\mathrm{HCl} 0.05 \mathrm{~mol} \mathrm{~L}^{-1}\right.$ $+\mathrm{H}_{2} \mathrm{SO}_{4} 0.025 \mathrm{~mol} \mathrm{~L}^{-1}$, according to Claessen (1997). For $\mathrm{Na}$ and $\mathrm{K}$ determinations, a flame photometer was used, and other nutrients were measured in an atomic absorption spectrophotometer.

Plants in the flowering stage were evaluated by height growth, stem base diameter, inflorescences, dry biomass accumulation, and nutrient content in roots and aerial parts. Sampling was performed following a zig-zag path, and six plants per plot were collected. Plant aerial parts were harvested, and roots were gently removed from the soil. Roots were washed in tap water on a sieve ( $2 \mathrm{~mm}$ mesh), passed through distilled and deionized water, and dried in an oven with forced ventilation at $65^{\circ} \mathrm{C}$. Shoots were also passed through deionized water before being dried in the oven. After the determination of dry biomass, fractions of different plant parts were ground and subjected to digestion in a muffle furnace at $550^{\circ} \mathrm{C}$, for 2 hours, and analyzed for macro and micronutrients according to Silva (2009).

The economic analysis was carried out by common financial indicators, all of which concentrated in the operating results of the production system used. Yield from the ornamental sunflower stems, in treatments with the types of water used, enabled the potential of crop production to be designed, in soil irrigated with produced water. Based on the production of three successive productive cycles in 2012 and 2013, the annual yields were estimated to be 90,000 stems per hectare irrigated with APO, and 85,000 stems per hectare irrigated with APF or ACA. For calculation of the revenues, data obtained during the 2012 and 2013 harvests and the crop yield were considered. Stems considered here showed the lengths, stalk diameters, and sunflower heads that are adopted for flower classification of Veiling Holambra, in São Paulo, SP, Brazil, and they are accepted in the domestic market.

Costs and revenues of the ornamental sunflower production system are based on the prices which were in effect during the first semester of 2013, considering quality criteria for the types of flower stems as proposed by Curti et al (2012). In order to obtain the cost of water $\left(\mathrm{m}^{3}\right)$, values were considered in US dollar and, in parentheses, values are presented in the Brazilian currency, the real: PWO, \$7.66 (R \$ 16.56); PWF, \$1.03 (R\$ 2.22); GW, \$0.55 (R\$ 1.20). The costs involved engineering calculations of the layout, filtration capacity, and treatment of produced water in the pilot plant (capacity for each water was $40 \mathrm{~m}^{3}$ per day), and in the pumping pipeline for the experimental area. The amount of manual labor was estimated based on services provided by rural workers in the region. The yield was calculated based on production rods in irrigated plots, having as a basis the average price (US\$ 6.94 for bouquet-type arrangement with six sunflower stems), obtained in the market of Southeastern Brazil.

The results of soil analyses taken over the production cycles, according to separate soil depths, as well as the data of dry biomass and nutrient content accumulated in the roots and in the aerial parts of plants were analyzed statistically. In the analyses, an arrangement in a split-plot was considered, while the main treatments represented the types of water, and the secondary treatments represented the cycles of production. In the variance analysis, the GLM (general linear models procedure) of SAS 9.2 (Allison, 2010) was adopted, and the means were compared using the Tukey's test, at $5 \%$ probability.

\section{Results and Discussion}

The ornamental sunflower plants were successfully established in areas subjected to drip irrigation with oilfield produced water, and the shoot growth visual was similar to that observed with plants irrigated with the control groundwater from Açu aquifer. The volume of different types of water applied to the soil plus rainfall, in each stem production cycle, indicated a small variation (Figure 1), which was a consequence of adjustments in the automated irrigation system. In addition, a total of $664 \mathrm{~mm}$ rain was registered between the end of the first cycle (October 2012) and the beginning of the second one (April 2013), which possibly contributed to the leaching of salts in the soil profile.

The types of water used show differences for electrical conductivity and $\mathrm{Na}^{+}$concentration (Table 1), which 
seems to justify a restriction of use in an irrigation agrosystem. Despite its treatment through sand filters and cation exchange columns in the wastewater treatment unit, PWF still contained high levels of sodium $\left(18.48 \mathrm{mmol}_{\mathrm{c}} \mathrm{L}^{-1}\right)$, which led to its classification in the category of severe restricted use for irrigation (Ayers \& Westcot, 1985). According to these authors, PWO and GW would also be placed in a category of use with moderate restriction. It is worth noting that water from wells outside the FZB and from the aquifer Jandaíra, closer to the surface compared to the Açu aquifer, has already been considered to be brackish (Melo et al., 2007), and it may also not be very suitable for irrigation of salt-sensitive plants.

After the crop cycles, some baseline chemical characteristics of the soil changed (Table 2), especially the concentration of salts in surface layers. The interaction between the types of water and the production cycles of ornamental sunflower stems affected the levels of cations in the saturated extract $\left(\mathrm{K}^{+}, \mathrm{Na}^{+}, \mathrm{Ca}^{2+}\right.$, and ESP), as well as the concentrations of the microelements $\mathrm{Fe}$ and $\mathrm{Zn}$ in the first upper layers of the soil (Table 3), while for other parameters no significant effect from the interaction of those factors was detected (Table 4). There was a greater increase

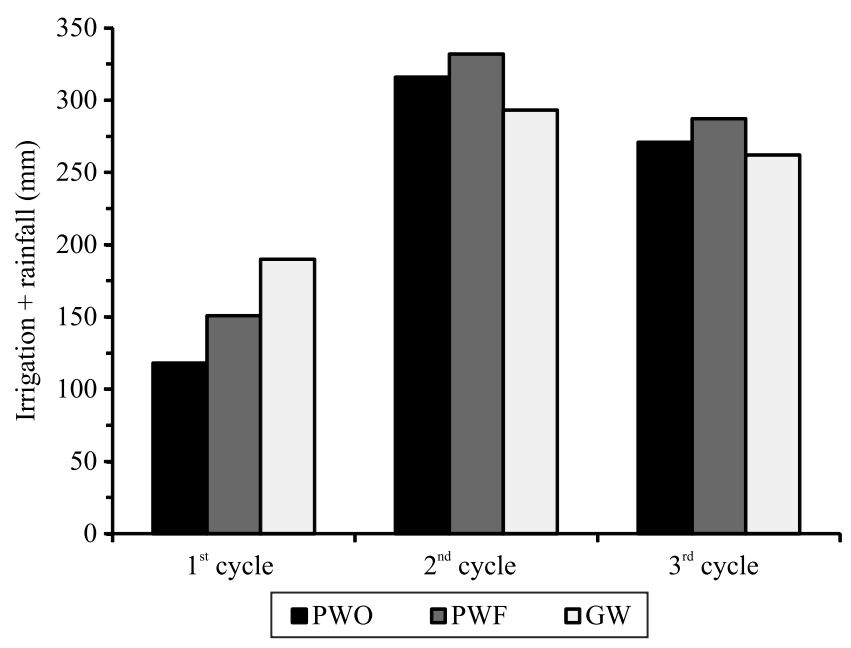

Figure 1. Mean volume of applied water plus recorded rainfall during the ornamental sunflower production cycles at the Belém farm in the municipality of Aracati, CE, Brazil. The cycles and rainwater corresponded to 64 days and zero $\mathrm{mm}$ ( $1^{\text {st }}$ cycle $), 78$ days and $145 \mathrm{~mm}\left(2^{\text {nd }}\right.$ cycle $), 71$ days and $0.8 \mathrm{~mm}\left(3^{\text {rd }}\right.$ cycle). Types of water: PWO, produced water treated by reverse osmosis; PWF, produced water treated by filtration; GW, groundwater from the Açu aquifer. of $\mathrm{K}^{+}$content, during the third cycle, for all five layers (up to $1 \mathrm{~m}$ depth) of soil that received PWF, than there was in the other irrigation treatments (Table 3). A higher concentration of $\mathrm{K}^{+}$in the soil may have been due to fertilizers applied to the crop, and the supply of that element with PWF, which in fact had a higher concentration of $\mathrm{K}^{+}$, in comparison to the other types of water used. With the application of PWF, an increase of $\mathrm{Na}^{+}$content was also observed in some soil layers (20-40, 40-60, and 60-80 cm), during the first two cycles. After the last cycle, $\mathrm{Na}^{+}$was accumulated in layers below the root zone (40-60 and 60-80 cm), in comparison to other irrigation treatments.

It should be noted that PWF was brackish water (Table 1), and its application during the first production cycle $(151 \mathrm{~mm})$ increased the exchangeable sodium from $0.86 \%$, in the upper soil layer (Table 2), to $28.6 \%$ after the first harvest of flower stems (Table 3). The application of PWF may have started a salinization process, during the first production cycle, reaching $\mathrm{EC}=3.11 \mathrm{dS} \mathrm{m}^{-1}$ within the upper soil layer (Table 4); however, this value did not differ from those observed in other irrigation treatments. A variation of EC between 2 and $4 \mathrm{dS} \mathrm{m}^{-1}$ can provide an early warning for salinization potential within the surface soil (Sanchez et al., 2003), although the saline character is considered only with changes of $\mathrm{EC} \geq 4 \mathrm{dSm}^{-1}$.

Over the last production cycles of sunflower stems, the soil treated with PWF also showed a reduction of ESP values, in relation to those observed at the end of the first production cycle. There was possibly a beneficial effect of rainfall recorded during the first inter-harvest period (from October 2012 to April 2013), contributing to the leaching of soluble salts along the soil profile. Other techniques, such as the application of gypsum and leaching by drainage (Oliveira et al., 2016), can also preserve soil properties.

In the first production cycle, the use of PWF led to a reduction of $\mathrm{Ca}^{2+}$ content at $20-40 \mathrm{~cm}$ soil depth, in comparison to treatment with GW. Control groundwater was rich in $\mathrm{Ca}^{2+}\left(0.22 \mathrm{mmol}_{\mathrm{c}} \mathrm{L}^{-1}\right)$, and a possible mixing with PWF irrigation could have served as a nutrient source for plants. Moreover, the interaction between the types of water and production cycles influenced the $\mathrm{Zn}$ content of the first layer $(0-20 \mathrm{~cm})$, and Fe up to $40 \mathrm{~cm}$ depth in the soil (Table 3); Fe accumulated over the production cycles in soil treated with PWO. Among the irrigation water used, PWO indicated the 
highest concentration of Fe $\left(0.381 \mathrm{mg} \mathrm{L}^{-1}\right)$ (Table 1), and, although that concentration did not represent an immediate risk, the element should also be monitored over a long period of irrigation. Using water with increased levels of Fe (from 0.5 to $1.5 \mathrm{mg} \mathrm{L}^{-1}$ ) reduced the growth of ornamental sunflower plants 'Sunbright Supreme' (Oliveira et al., 2014).

Other soil parameters varied depending on the types of water and production cycles (Table 4), without any significant effect on the interaction of these factors. The treatment using PWF increased the content of $\mathrm{Na}^{+}(0-20$ and $80-100 \mathrm{~cm}$ ), $\mathrm{pH}$ values, and ESP (up to

Table 1. The mean values of $\mathrm{pH}$, electric conductivity (EC), bicarbonate, and the concentration of some elements of the types of water used for irrigation experiment in the field.

\begin{tabular}{lccc}
\hline \multirow{2}{*}{ Parameter } & \multicolumn{3}{c}{ Water type } \\
\cline { 2 - 4 } & PWO & PWF & GW \\
\hline $\mathrm{pH}$ & 7.56 & $8.46^{(1)}$ & 8.11 \\
$\mathrm{EC}\left(\mathrm{dS} \mathrm{m}^{-1}\right)$ & 0.53 & $2.67^{(1)}$ & 0.69 \\
$\mathrm{HCO}_{3}^{-}\left(\mathrm{mmol}_{\mathrm{c}} \mathrm{L}^{-1}\right)$ & $2.79^{(1)}$ & $3.51^{(1)}$ & 1.44 \\
$\mathrm{~K}+\left(\mathrm{mmol}_{\mathrm{c}} \mathrm{L}^{-1}\right)$ & 0.40 & 0.70 & 0.17 \\
$\mathrm{Ca}^{2+}\left(\mathrm{mmol}_{\mathrm{c}} \mathrm{L}^{-1}\right)$ & 0.10 & 0.16 & 0.22 \\
$\mathrm{Mg}^{2+}\left(\mathrm{mmol}_{\mathrm{c}} \mathrm{L}^{-1}\right)$ & 0.29 & 1.03 & 0.12 \\
$\mathrm{Na}^{+}\left(\mathrm{mmol}_{\mathrm{c}} \mathrm{L}^{-1}\right)$ & $4.54^{(1)}$ & $18.48^{(2)}$ & $8.31^{(1)}$ \\
$\mathrm{Fe}\left(\mathrm{mg} \mathrm{L}^{-1}\right)$ & 0.381 & 0.064 & 0.065 \\
$\mathrm{Mn}\left(\mathrm{mg} \mathrm{L}^{-1}\right)$ & 0.007 & 0.002 & 0.004 \\
$\mathrm{Zn}\left(\mathrm{mg} \mathrm{L}^{-1}\right)$ & 0.031 & 0.008 & 0.004 \\
\hline
\end{tabular}

Water types: PWO, produced water treated by reverse osmosis; PWF, produced water treated by filtration; $\mathrm{GW}$, groundwater from the Açu aquifer. Degree of restriction on use: severe ${ }^{(2)}$, slight to moderate ${ }^{(1)}$, and none (unnumbered), according to Ayers \& Westcot (1985).

Table 2. Mean values of $\mathrm{pH}$ in water, electrical conductivity (EC), exchangeable cations from the saturation extract, and micronutrients extracted from soil collected from five layers in the pre-cultivation period, at the Belém farm in the municipality of Aracati, in the state of Ceará.

\begin{tabular}{lrrrrc}
\hline Parameter & \multicolumn{5}{c}{ Soil depth $(\mathrm{cm})$} \\
\cline { 2 - 6 } & $0-20$ & $20-40$ & $40-60$ & $60-80$ & $80-100$ \\
\hline $\mathrm{pH} \mathrm{in} \mathrm{H}_{2} \mathrm{O}(1: 2.5)$ & 6.42 & 6.56 & 6.68 & 6.71 & 6.72 \\
$\left.\mathrm{EC}(\mathrm{dS} \mathrm{m})^{-1}\right)$ & 0.18 & 0.09 & 0.08 & 0.08 & 0.07 \\
$\mathrm{~K}^{+}\left(\mathrm{mmol}_{\mathrm{c}} \mathrm{kg}^{-1}\right)$ & 0.55 & 0.32 & 0.27 & 0.25 & 0.24 \\
$\mathrm{Ca}^{2+}\left(\mathrm{mmol}_{\mathrm{c}} \mathrm{kg}^{-1}\right)$ & 12.62 & 9.58 & 7.91 & 7.38 & 6.87 \\
$\mathrm{Mg}^{2+}\left(\mathrm{mmol}_{\mathrm{c}} \mathrm{kg}^{-1}\right)$ & 2.23 & 1.58 & 1.40 & 1.31 & 1.17 \\
$\mathrm{Na}^{+}\left(\mathrm{mmol}_{\mathrm{c}} \mathrm{kg}^{-1}\right)$ & 0.13 & 0.13 & 0.13 & 0.13 & 0.12 \\
$\mathrm{ESP}(\%)$ & 0.86 & 1.11 & 1.43 & 1.54 & 1.48 \\
$\mathrm{Fe}\left(\mathrm{mg} \mathrm{kg}^{-1}\right)$ & 7.14 & 8.26 & 7.66 & 8.84 & 9.27 \\
$\mathrm{Mn}\left(\mathrm{mg} \mathrm{kg}^{-1}\right)$ & 18.44 & 14.86 & 10.05 & 5.20 & 7.48 \\
$\mathrm{Zn}\left(\mathrm{mg} \mathrm{kg}^{-1}\right)$ & 0.83 & 0.31 & 0.17 & 0.15 & 0.18 \\
\hline
\end{tabular}

Exchangeable sodium percentage (ESP) $=\left[100 \mathrm{Na}^{+}+\mathrm{Ca}^{2+}+\mathrm{Mg}^{2+}+\mathrm{K}^{+}+\right.$ $\mathrm{H}^{+}+\mathrm{Al}^{3+}$ ] of soil. Fractions of sand ranged from $946 \mathrm{~g}$ to $948 \mathrm{~g} \mathrm{~kg}^{-1}$ within the top meter horizons of the soil (Crisostomo et al., 2016).
Table 3. Mean values of parameters of samples collected at five soil depths, as a result of irrigation treatments and ornamental sunflower production cycles ${ }^{(1)}$.

\begin{tabular}{|c|c|c|c|c|}
\hline Parameter & Water type & Cycle 1 & Cycle 2 & Cycle 3 \\
\hline & \multicolumn{4}{|c|}{ First soil depth $(0-20 \mathrm{~cm})$} \\
\hline \multirow[t]{3}{*}{$\mathrm{K}^{+}\left(\mathrm{mmol}_{\mathrm{c}} \mathrm{kg}^{-1}\right)$} & PWO & $2.25 \mathrm{Aa}$ & $0.85 \mathrm{Aa}$ & $3.78 \mathrm{Ba}$ \\
\hline & PWF & $2.04 \mathrm{Ab}$ & $1.36 \mathrm{Ab}$ & 8.89Aa \\
\hline & GW & $2.57 \mathrm{Aa}$ & $0.81 \mathrm{Aa}$ & $3.92 \mathrm{Ba}$ \\
\hline \multirow[t]{3}{*}{ ESP $(\%)$} & PWO & $5.90 \mathrm{Ca}$ & $8.51 \mathrm{Aa}$ & $7.71 \mathrm{Aa}$ \\
\hline & PWF & $28.83 \mathrm{Aa}$ & $13.77 \mathrm{Ab}$ & $13.36 \mathrm{Ab}$ \\
\hline & GW & $13.37 \mathrm{Ba}$ & $9.95 \mathrm{Aa}$ & $11.57 \mathrm{Aa}$ \\
\hline \multirow[t]{3}{*}{$\mathrm{Fe}\left(\mathrm{mg} \mathrm{kg}^{-1}\right)$} & PWO & $12.85 \mathrm{Ab}$ & $19.93 \mathrm{Ab}$ & $39.03 \mathrm{Aa}$ \\
\hline & PWF & $14.09 \mathrm{Aa}$ & $17.56 \mathrm{Aa}$ & $16.94 \mathrm{Ba}$ \\
\hline & GW & $14.71 \mathrm{Aa}$ & $16.59 \mathrm{Aa}$ & $13.05 \mathrm{Ba}$ \\
\hline \multirow[t]{4}{*}{$\mathrm{Zn}\left(\mathrm{mg} \mathrm{kg}^{-1}\right)$} & PWO & $6.74 \mathrm{Ab}$ & $12.85 \mathrm{Aa}$ & $4.28 \mathrm{Ab}$ \\
\hline & PWF & 6.96Aa & $9.41 \mathrm{ABa}$ & $5.61 \mathrm{Aa}$ \\
\hline & GW & $8.17 \mathrm{Aa}$ & $6.50 \mathrm{Ba}$ & $6.70 \mathrm{Aa}$ \\
\hline & \multicolumn{4}{|c|}{ Second soil depth $(20-40 \mathrm{~cm})$} \\
\hline \multirow[t]{3}{*}{$\mathrm{K}^{+}\left(\mathrm{mmol}_{\mathrm{c}} \mathrm{kg}^{-1}\right)$} & PWO & $1.98 \mathrm{Aa}$ & $1.21 \mathrm{Aa}$ & $1.73 \mathrm{Ba}$ \\
\hline & PWF & $1.25 \mathrm{Ab}$ & $1.04 \mathrm{Ab}$ & $5.50 \mathrm{Aa}$ \\
\hline & GW & $1.43 \mathrm{Aa}$ & $1.03 \mathrm{Aa}$ & $2.49 \mathrm{Ba}$ \\
\hline \multirow[t]{3}{*}{$\mathrm{Ca}^{2+}\left(\mathrm{mmol}_{\mathrm{c}} \mathrm{kg}^{-1}\right)$} & PWO & $11.44 \mathrm{ABa}$ & $9.08 \mathrm{Aa}$ & $6.40 \mathrm{Ab}$ \\
\hline & PWF & $10.06 \mathrm{Bab}$ & $11.92 \mathrm{Aa}$ & $8.30 \mathrm{Ab}$ \\
\hline & GW & $13.79 \mathrm{Aa}$ & $8.71 \mathrm{Ab}$ & $7.83 \mathrm{Ab}$ \\
\hline \multirow[t]{3}{*}{$\mathrm{Na}^{+}\left(\mathrm{mmol}_{\mathrm{c}} \mathrm{kg}^{-1}\right)$} & PWO & $0.77 \mathrm{Ba}$ & $1.00 \mathrm{Ba}$ & $1.91 \mathrm{Aa}$ \\
\hline & PWF & 7.14Aa & $3.91 \mathrm{Ab}$ & $3.31 \mathrm{Ab}$ \\
\hline & GW & $2.52 \mathrm{Ba}$ & $1.75 \mathrm{ABa}$ & $2.32 \mathrm{Aa}$ \\
\hline \multirow[t]{3}{*}{$\operatorname{ESP}(\%)$} & PWO & $5.04 \mathrm{Cb}$ & 7.24Bab & $15.29 \mathrm{Aa}$ \\
\hline & PWF & $34.81 \mathrm{Aa}$ & $19.93 \mathrm{Ab}$ & $15.43 \mathrm{Ab}$ \\
\hline & GW & $13.25 \mathrm{Ba}$ & $13.19 \mathrm{ABa}$ & $14.38 \mathrm{Aa}$ \\
\hline \multirow[t]{4}{*}{$\mathrm{Fe}\left(\mathrm{mg} \mathrm{kg}^{-1}\right)$} & PWO & $6.13 \mathrm{Ab}$ & $4.59 \mathrm{Ab}$ & $48.38 \mathrm{Aa}$ \\
\hline & PWF & $5.88 \mathrm{Aa}$ & $5.08 \mathrm{Aa}$ & $8.16 \mathrm{Ba}$ \\
\hline & GW & 7.73Aa & 6.68Aa & $10.91 \mathrm{Ba}$ \\
\hline & \multicolumn{4}{|c|}{ Third soil depth $(40-60 \mathrm{~cm})$} \\
\hline \multirow[t]{3}{*}{$\mathrm{K}^{+}\left(\mathrm{mmol}_{\mathrm{c}} \mathrm{kg}^{-1}\right)$} & PWO & $0.98 \mathrm{Aa}$ & $1.31 \mathrm{Aa}$ & $1.43 \mathrm{Ba}$ \\
\hline & PWF & $1.29 \mathrm{Ab}$ & $1.29 \mathrm{Ab}$ & 4.76Aa \\
\hline & GW & $1.38 \mathrm{Ab}$ & $1.25 \mathrm{Ab}$ & $1.93 \mathrm{Bb}$ \\
\hline \multirow[t]{4}{*}{$\mathrm{Na}^{+}\left(\mathrm{mmol}_{\mathrm{c}} \mathrm{kg}^{-1}\right)$} & PWO & $0.19 \mathrm{Ba}$ & $1.04 \mathrm{Ba}$ & $1.06 \mathrm{Ba}$ \\
\hline & PWF & $4.85 \mathrm{Aa}$ & $3.13 \mathrm{Ab}$ & $4.53 \mathrm{Aa}$ \\
\hline & GW & $1.33 \mathrm{Ba}$ & $1.16 \mathrm{Ba}$ & $2.69 \mathrm{Ba}$ \\
\hline & \multicolumn{4}{|c|}{ Fourth soil depth $(60-80 \mathrm{~cm})$} \\
\hline \multirow[t]{3}{*}{$\mathrm{K}^{+}\left(\mathrm{mmol}_{\mathrm{c}} \mathrm{kg}^{-1}\right)$} & PWO & $0.40 \mathrm{Aa}$ & $0.93 \mathrm{Aa}$ & $1.29 \mathrm{Ba}$ \\
\hline & PWF & $1.09 \mathrm{Ab}$ & $1.28 \mathrm{Ab}$ & $4.52 \mathrm{Aa}$ \\
\hline & GW & $0.88 \mathrm{Aa}$ & $1.00 \mathrm{Aa}$ & $1.51 \mathrm{Ba}$ \\
\hline \multirow[t]{4}{*}{$\mathrm{Na}^{+}\left(\mathrm{mmol}_{\mathrm{c}} \mathrm{kg}^{-1}\right)$} & PWO & $0.18 \mathrm{Ba}$ & $0.93 \mathrm{Ba}$ & $1.11 \mathrm{Ba}$ \\
\hline & PWF & 3.89Aa & $3.00 \mathrm{Aa}$ & $4.18 \mathrm{Aa}$ \\
\hline & GW & $1.52 \mathrm{Bb}$ & $0.88 \mathrm{Bb}$ & 3.33Aa \\
\hline & \multicolumn{4}{|c|}{ Fifth soil depth $(80-100 \mathrm{~cm})$} \\
\hline \multirow[t]{3}{*}{$\mathrm{K}^{+}\left(\mathrm{mmol}_{\mathrm{c}} \mathrm{kg}^{-1}\right)$} & PWO & $0.43 \mathrm{Aa}$ & $0.52 \mathrm{Ba}$ & $1.02 \mathrm{Ba}$ \\
\hline & PWF & $0.76 \mathrm{Ab}$ & $1.11 \mathrm{Ab}$ & $4.08 \mathrm{Aa}$ \\
\hline & GW & $0.44 \mathrm{Ab}$ & $0.58 \mathrm{ABb}$ & $1.50 \mathrm{Ba}$ \\
\hline
\end{tabular}

${ }^{(1)}$ Means followed by equal letters, lowercase in the lines and uppercase in the columns, indicate no significant differences by the Tukey's test, at $5 \%$ probability. Types of water: PWO, produced water treated by reverse osmosis; PWF, produced water treated by filtration; GW, groundwater from Açu aquifer. 
Table 4. Mean values of $\mathrm{pH}$, electrical conductivity (EC), exchangeable cations, and micronutrients extracted from soil samples collected at five soil depths, as a result of irrigation treatments and ornamental sunflower production cycles ${ }^{(1)}$.

\begin{tabular}{|c|c|c|c|c|c|c|}
\hline \multirow[t]{2}{*}{ Parameter } & \multicolumn{3}{|c|}{ Water type } & \multicolumn{3}{|c|}{ Production cycle } \\
\hline & PWO & PWF & GW & One & Two & Three \\
\hline & \multicolumn{6}{|c|}{ First soil depth $(0-20 \mathrm{~cm})$} \\
\hline $\mathrm{pH}$ in $\mathrm{H}_{2} \mathrm{O}(1: 2.5)$ & $7.74 \mathrm{a}$ & $8.36 \mathrm{a}$ & $7.39 \mathrm{a}$ & $8.31 \mathrm{a}$ & $8.23 \mathrm{a}$ & $7.39 \mathrm{~b}$ \\
\hline $\mathrm{EC}\left(\mathrm{dS} \mathrm{m} \mathrm{m}^{-1}\right)$ & $1.35 \mathrm{a}$ & $3.11 \mathrm{a}$ & $1.77 \mathrm{a}$ & $2.71 \mathrm{a}$ & $1.08 \mathrm{~b}$ & $2.44 \mathrm{ab}$ \\
\hline $\mathrm{Na}^{+}\left(\mathrm{mmol}_{\mathrm{c}} \mathrm{kg}^{-1}\right)$ & $2.20 \mathrm{~b}$ & $6.35 \mathrm{a}$ & $3.51 \mathrm{ab}$ & $5.03 \mathrm{a}$ & $3.38 \mathrm{a}$ & $3.65 \mathrm{a}$ \\
\hline $\mathrm{Ca}^{2+}\left(\mathrm{mmol}_{\mathrm{c}} \mathrm{kg}^{-1}\right)$ & $20.59 a$ & $20.24 \mathrm{a}$ & $19.33 \mathrm{a}$ & $21.84 \mathrm{a}$ & $20.55 \mathrm{a}$ & $17.78 \mathrm{a}$ \\
\hline $\mathrm{Mg}^{2+}\left(\mathrm{mmol}_{\mathrm{c}} \mathrm{kg}^{-1}\right)$ & $4.65 \mathrm{a}$ & $4.69 \mathrm{a}$ & $4.86 \mathrm{a}$ & $1.42 \mathrm{c}$ & $5.16 \mathrm{~b}$ & $7.61 \mathrm{a}$ \\
\hline \multirow[t]{2}{*}{$\operatorname{Mn}\left(\mathrm{mg} \mathrm{kg}^{-1}\right)$} & $28.05 \mathrm{a}$ & $29.37 \mathrm{a}$ & $23.91 \mathrm{a}$ & $36.80 \mathrm{a}$ & $26.50 \mathrm{~b}$ & $18.04 \mathrm{~b}$ \\
\hline & \multicolumn{6}{|c|}{ Second soil depth $(20-40 \mathrm{~cm})$} \\
\hline $\mathrm{pH}$ in $\mathrm{H}_{2} \mathrm{O}(1: 2.5)$ & $7.52 b$ & $8.11 \mathrm{a}$ & $7.96 \mathrm{ab}$ & $8.17 \mathrm{a}$ & $8.11 \mathrm{a}$ & $7.31 \mathrm{~b}$ \\
\hline $\mathrm{EC}\left(\mathrm{dS} \mathrm{m} \mathrm{m}^{-1}\right)$ & $0.71 \mathrm{a}$ & $1.60 \mathrm{a}$ & $1.25 \mathrm{a}$ & $1.72 \mathrm{a}$ & $0.52 \mathrm{a}$ & $1.33 \mathrm{a}$ \\
\hline $\mathrm{Mg}^{2+}\left(\mathrm{mmol}_{\mathrm{c}} \mathrm{kg}^{-1}\right)$ & $1.95 \mathrm{a}$ & $3.25 \mathrm{a}$ & $2.30 \mathrm{a}$ & $1.26 \mathrm{~b}$ & $2.16 \mathrm{ab}$ & $4.07 \mathrm{~b}$ \\
\hline $\operatorname{Mn}\left(\mathrm{mg} \mathrm{kg}^{-1}\right)$ & $10.95 \mathrm{a}$ & $10.69 \mathrm{a}$ & $10.44 \mathrm{a}$ & $16.28 \mathrm{a}$ & $8.65 b$ & $7.15 \mathrm{~b}$ \\
\hline \multirow[t]{2}{*}{$\mathrm{Zn}\left(\mathrm{mg} \mathrm{kg}^{-1}\right)$} & $1.07 \mathrm{a}$ & $1.12 \mathrm{a}$ & $1.17 \mathrm{a}$ & $16.28 \mathrm{a}$ & $8.65 \mathrm{~b}$ & $7.15 \mathrm{~b}$ \\
\hline & \multicolumn{6}{|c|}{ Third soil depth $(40-60 \mathrm{~cm})$} \\
\hline $\mathrm{pH}$ in $\mathrm{H}_{2} \mathrm{O}(1: 2.5)$ & $7.34 b$ & $8,14 \mathrm{a}$ & 7.92ab & $8.02 \mathrm{a}$ & $8.13 \mathrm{a}$ & $7.26 \mathrm{a}$ \\
\hline $\mathrm{EC}\left(\mathrm{dS} \mathrm{m} \mathrm{m}^{-1}\right)$ & $0.67 \mathrm{a}$ & $1.08 \mathrm{a}$ & $0.68 \mathrm{a}$ & $1.08 \mathrm{a}$ & $0.47 \mathrm{~b}$ & $0.88 \mathrm{ab}$ \\
\hline ESP $(\%)$ & $6.66 \mathrm{c}$ & $25.45 \mathrm{a}$ & $14.34 \mathrm{~b}$ & $14.49 \mathrm{a}$ & $12.92 \mathrm{a}$ & $19.06 \mathrm{a}$ \\
\hline $\mathrm{Ca}^{2+}\left(\mathrm{mmol}_{\mathrm{c}} \mathrm{kg}^{-1}\right)$ & $7.85 \mathrm{a}$ & $8.55 \mathrm{a}$ & $8.04 \mathrm{a}$ & $9.21 \mathrm{a}$ & $8.79 \mathrm{a}$ & $6.43 \mathrm{a}$ \\
\hline $\mathrm{Mg}^{2+}\left(\mathrm{mmol}_{\mathrm{c}} \mathrm{kg}^{-1}\right)$ & $1.80 \mathrm{a}$ & $1.80 \mathrm{a}$ & $1.26 \mathrm{a}$ & $1.21 \mathrm{a}$ & $1.49 \mathrm{a}$ & $2.15 \mathrm{a}$ \\
\hline $\mathrm{Fe}\left(\mathrm{mg} \mathrm{kg}^{-1}\right)$ & $19.12 \mathrm{a}$ & $7.01 \mathrm{a}$ & $8.28 \mathrm{a}$ & $6.32 \mathrm{ab}$ & $5.92 b$ & $22.18 \mathrm{a}$ \\
\hline $\operatorname{Mn}\left(\mathrm{mg} \mathrm{kg}^{-1}\right)$ & $8.89 \mathrm{a}$ & $8.41 \mathrm{a}$ & $5.99 \mathrm{a}$ & $11.16 \mathrm{a}$ & $6.51 \mathrm{~b}$ & $5.61 \mathrm{~b}$ \\
\hline \multirow[t]{2}{*}{$\mathrm{Zn}\left(\mathrm{mg} \mathrm{kg}^{-1}\right)$} & $0.96 \mathrm{a}$ & $1.39 \mathrm{a}$ & $0.64 \mathrm{a}$ & $0.81 \mathrm{a}$ & $1.02 \mathrm{a}$ & $1.16 \mathrm{a}$ \\
\hline & \multicolumn{6}{|c|}{ Fourth soil depth $(60-80 \mathrm{~cm})$} \\
\hline $\mathrm{pH}$ in $\mathrm{H}_{2} \mathrm{O}(1: 2.5)$ & $7.21 \mathrm{~b}$ & $7.98 \mathrm{a}$ & $7.81 \mathrm{~b}$ & $7.95 \mathrm{a}$ & $8.05 \mathrm{a}$ & $7.00 \mathrm{~b}$ \\
\hline $\mathrm{EC}\left(\mathrm{dS} \mathrm{m} \mathrm{m}^{-1}\right)$ & $0.38 \mathrm{~b}$ & $0.87 \mathrm{a}$ & $0.63 \mathrm{ab}$ & $0.64 \mathrm{ab}$ & $0.45 \mathrm{~b}$ & $0.79 \mathrm{a}$ \\
\hline $\operatorname{ESP}(\%)$ & $7.30 \mathrm{c}$ & $28.44 \mathrm{a}$ & $14.83 \mathrm{~b}$ & $14.91 \mathrm{a}$ & $15.79 \mathrm{a}$ & $19.86 \mathrm{a}$ \\
\hline $\mathrm{Ca}^{2+}\left(\mathrm{mmol}_{\mathrm{c}} \mathrm{kg}^{-1}\right)$ & $7.07 \mathrm{a}$ & $6.05 \mathrm{a}$ & $8.69 \mathrm{a}$ & $8.18 \mathrm{a}$ & $6.83 \mathrm{a}$ & $6.81 \mathrm{a}$ \\
\hline $\mathrm{Mg}^{2+}\left(\mathrm{mmol}_{\mathrm{c}} \mathrm{kg}^{-1}\right)$ & $1.27 \mathrm{a}$ & $1.69 \mathrm{a}$ & $1.31 \mathrm{a}$ & $1.18 \mathrm{a}$ & $0.96 \mathrm{a}$ & $2.13 \mathrm{a}$ \\
\hline $\mathrm{Cu}\left(\mathrm{mg} \mathrm{kg}^{-1}\right)$ & $0.10 \mathrm{a}$ & $0.08 \mathrm{a}$ & $0.20 \mathrm{a}$ & $0.29 \mathrm{a}$ & $0.09 \mathrm{~b}$ & $0.01 \mathrm{~b}$ \\
\hline $\mathrm{Fe}\left(\mathrm{mg} \mathrm{kg}^{-1}\right)$ & $9.64 \mathrm{a}$ & $8.89 \mathrm{a}$ & $9.30 \mathrm{a}$ & $8.63 \mathrm{~b}$ & $6.74 \mathrm{~b}$ & $12.47 \mathrm{a}$ \\
\hline $\operatorname{Mn}\left(\mathrm{mg} \mathrm{kg}^{-1}\right)$ & $8.03 \mathrm{a}$ & $7.20 \mathrm{a}$ & $6.38 \mathrm{a}$ & $9.52 \mathrm{a}$ & $5.61 \mathrm{~b}$ & $6.47 \mathrm{ab}$ \\
\hline \multirow[t]{2}{*}{$\mathrm{Zn}\left(\mathrm{mg} \mathrm{kg}^{-1}\right)$} & $0.70 \mathrm{a}$ & $0.67 \mathrm{a}$ & $0.69 \mathrm{a}$ & $0.59 \mathrm{~b}$ & $0.96 \mathrm{~b}$ & $0.50 \mathrm{~b}$ \\
\hline & \multicolumn{6}{|c|}{ Fifth soil depth $(80-100 \mathrm{~cm})$} \\
\hline $\mathrm{pH}$ in $\mathrm{H}_{2} \mathrm{O}(1: 2.5)$ & $7.16 \mathrm{~b}$ & $7.88 \mathrm{a}$ & $7.77 \mathrm{a}$ & $7.89 \mathrm{a}$ & $7.99 \mathrm{a}$ & $6.93 b$ \\
\hline $\mathrm{EC}\left(\mathrm{dS} \mathrm{m} \mathrm{m}^{-1}\right)$ & $0.39 \mathrm{a}$ & $0.84 \mathrm{a}$ & $0.58 \mathrm{a}$ & $0.61 \mathrm{ab}$ & $0.41 \mathrm{~b}$ & $0.78 \mathrm{a}$ \\
\hline $\mathrm{Na}^{+}\left(\mathrm{mmol}_{\mathrm{c}} \mathrm{kg}^{-1}\right)$ & $0.61 \mathrm{~b}$ & $3.34 \mathrm{a}$ & $1.39 \mathrm{~b}$ & $1.53 \mathrm{~b}$ & $1.40 \mathrm{~b}$ & $2.42 \mathrm{a}$ \\
\hline $\operatorname{ESP}(\%)$ & $6.31 \mathrm{~b}$ & $24.03 \mathrm{a}$ & $12.96 \mathrm{~b}$ & $13.21 \mathrm{a}$ & $12.10 \mathrm{a}$ & $17.99 \mathrm{a}$ \\
\hline $\mathrm{Ca}^{2+}\left(\mathrm{mmol}_{\mathrm{c}} \mathrm{kg}^{-1}\right)$ & $7.20 \mathrm{a}$ & $7.27 \mathrm{a}$ & $8.00 \mathrm{a}$ & $8.23 \mathrm{a}$ & $7.53 \mathrm{a}$ & $6.71 \mathrm{a}$ \\
\hline $\mathrm{Mg}^{2+}\left(\mathrm{mmol}_{\mathrm{c}} \mathrm{kg}^{-1}\right)$ & $1.46 \mathrm{a}$ & $1.46 \mathrm{a}$ & $1.52 \mathrm{a}$ & $1.01 \mathrm{a}$ & $1.31 \mathrm{a}$ & $2.13 \mathrm{a}$ \\
\hline $\mathrm{Fe}\left(\mathrm{mg} \mathrm{kg}^{-1}\right)$ & $26.76 \mathrm{a}$ & $10.53 \mathrm{a}$ & $16.29 \mathrm{a}$ & $9.94 \mathrm{~b}$ & $6.80 \mathrm{~b}$ & $36.84 \mathrm{a}$ \\
\hline $\operatorname{Mn}\left(\mathrm{mg} \mathrm{kg}^{-1}\right)$ & $7.87 \mathrm{a}$ & $7.06 \mathrm{a}$ & $6.73 \mathrm{a}$ & $9.27 \mathrm{a}$ & $4.91 \mathrm{a}$ & $7.49 \mathrm{a}$ \\
\hline $\mathrm{Zn}\left(\mathrm{mg} \mathrm{kg}^{-1}\right)$ & $0.80 \mathrm{a}$ & $1.31 \mathrm{a}$ & $0.71 \mathrm{a}$ & $0.65 \mathrm{a}$ & $1.56 \mathrm{a}$ & $0.61 \mathrm{a}$ \\
\hline
\end{tabular}

(1)Means followed by equal letters in the lines indicate no significant differences by the Tukey's test, at 5\% probability. Types of water: PWO, produced water treated by reverse osmosis; PWF, produced water treated by filtration; GW, groundwater from Açu aquifer. 
$100 \mathrm{~cm}$ depth), in comparison to the soil irrigated with PWO. In general, these variations are consistent with those previously shown in Table 3 . There was also a decrease of $\mathrm{pH}$ values, $\mathrm{EC}$, and $\mathrm{Mn}$ content for some layers of the soil analyzed during the second and third cycles (Table 4). Concentrations of $\mathrm{Mg}^{2+}(0-20 \mathrm{~cm})$ and Fe (layer of 40-60, 60-80, and 80-100 cm) were greater during the third cycle, especially compared to the second cycle. The tendency of buildup of these nutrients, during the production cycle, may be due to the irrigation and organic fertilization of plants, and their availability in the soil is also associated with the formation of complexes with organic acids and mineral colloids. Organic compounds form chelates with the metals in the soil, favoring their absorption by plants (Melo et al., 2006) and their mobility in the soil profile.

Plant growth parameters and nutrient contents in roots and aerial parts were also influenced by the types of water used and by the cycles of production of flower stems (Tables 5 and 6). Plant performance was satisfactory and very similar in irrigated plots with PWO and GW, in comparison to the irrigation with PWF (Table 5), in which a lower production of biomass was detected during the first production cycle. Also, the treatment with PWF was unfavorable for the radial growth of plant stems, during the third cycle, in comparison to treatment with PWO. These effects on plant performance may have been due to the accumulation of salts in the soil profile, especially exchangeable sodium. However, an occasional reduction of shoot growth and biomass production does not necessarily imply a loss of commercial value of sunflower stems (Maciel et al., 2012; Oliveira et al., 2014). The strong growth of shoots is undesirable for ornamental plants, and there is a preference for ornamental sunflowers with small heads measuring less than $15 \mathrm{~cm}$ of diameter (Carrillo-Ávila et al., 2015).

During the second and third production cycles, a higher density (3.3 plants $\mathrm{m}^{-2}$ ) was adopted, in order to obtain more stalks and small inflorescences. The smaller size of the heads was confirmed in the third cycle (Table 5). That practice aimed to meet consumer preferences for arrangements with sunflower stalks. It is worth mentioning that a much larger high density has been suggested (up to 11 plants $\mathrm{m}^{-2}$ ) for the production of small inflorescences (Khakwani et al., 2014), but this naturally affects the nutritional aspects of plants.
The interaction between water treatments and cycles significantly affected the concentration of some nutrients in the roots $(\mathrm{K}, \mathrm{Ca}, \mathrm{Na}, \mathrm{Fe}$, and $\mathrm{Zn})$ and in the aerial parts ( $\mathrm{K}, \mathrm{Mg}$ and $\mathrm{Na}$ ) (Table 6). During the first cycle, a lower concentration of $\mathrm{K}$ and $\mathrm{Zn}$ in the roots was observed, however, a higher content of $\mathrm{Na}$ was found in all parts of the plants irrigated with PWF. In subsequent cycles, this type of water also led to a significant accumulation of $\mathrm{Na}$ in the roots, particularly in relation to the use of PWO. The accumulation of $\mathrm{Na}$ in the lower parts of the plants had been reported in relation to ornamental sunflower 'Moonbright' irrigated with saline water (Grieve \& Poss, 2010). Furthermore, during the last production cycle, the use of PWF resulted in a reduction of $\mathrm{Mg}$ content in the aerial parts, and in an increase of $\mathrm{K}$ content in the roots and aerial parts of the plants, particularly in comparison to the treatment with GW. In a future work with plants of ornamental sunflower under irrigation with brackish water, different doses of $\mathrm{K}$ and $\mathrm{Mg}$ should be tested to find adequate levels of these nutrients in ornamental sunflower. An increase

Table 5. Plant growth and dry biomass accumulation of ornamental sunflower (Helianthus annus), as a result of irrigation treatments and plant production cycles ${ }^{(1)}$.

\begin{tabular}{llcc}
\hline Water type & Cycle 1 & Cycle 2 & Cycle 3 \\
\hline & \multicolumn{3}{c}{ Shoot height $(\mathrm{cm})$} \\
PWO & $72.9 \mathrm{cAB}$ & $108.4 \mathrm{aA}$ & $93.4 \mathrm{bA}$ \\
PWF & $63.0 \mathrm{cB}$ & $91.1 \mathrm{aB}$ & $70.4 \mathrm{bC}$ \\
GW & $77.8 \mathrm{bA}$ & $103.7 \mathrm{aA}$ & $80.9 \mathrm{bB}$ \\
\hline \multicolumn{4}{c}{ Stem base diameter $(\mathrm{mm})$} \\
PWO & $19.4 \mathrm{aA}$ & $14.9 \mathrm{bAC}$ & $16.6 \mathrm{bA}$ \\
PWF & $18.7 \mathrm{aA}$ & $16.2 \mathrm{bcA}$ & $14.2 \mathrm{cB}$ \\
GW & $20.0 \mathrm{aA}$ & $13.8 \mathrm{bC}$ & $14.9 \mathrm{bAB}$ \\
\hline \multicolumn{4}{c}{ Flower head diameter $(\mathrm{cm})$} \\
PWO & $13.6 \mathrm{aB}$ & - & $8.7 \mathrm{bB}$ \\
PWF & $13.2 \mathrm{aB}$ & - & $9.2 \mathrm{bA}$ \\
GW & $15.4 \mathrm{aA}$ & - & $8.6 \mathrm{bB}$ \\
\hline \multicolumn{4}{c}{ Root dry weight (g per plant) } \\
PWO & $21.4 \mathrm{aB}$ & $11.9 \mathrm{bA}$ & $12.5 \mathrm{bA}$ \\
PWF & $20.0 \mathrm{aB}$ & $11.6 \mathrm{bA}$ & $11.6 \mathrm{bA}$ \\
GW & $28.8 \mathrm{aA}$ & $9.0 \mathrm{bA}$ & $10.9 \mathrm{bA}$ \\
\hline \multicolumn{4}{c}{ Shoot dry weight (g per plant) } \\
PWO & $53.9 \mathrm{aBC}$ & $44.2 \mathrm{abA}$ & $376 \mathrm{bA}$ \\
PWF & $51.3 \mathrm{aC}$ & $38.4 \mathrm{bAB}$ & $29.2 \mathrm{bA}$ \\
GW & $66.9 \mathrm{aA}$ & $33.6 \mathrm{bB}$ & $31.2 \mathrm{bA}$ \\
\hline
\end{tabular}

${ }^{(1)}$ Means followed by equal letters, lowercase in the lines and uppercase in the columns, indicate no significant differences by the Tukey's test, at $5 \%$ probability. Types of water: PWO, produced water treated by reverse osmosis; PWF, produced water treated by filtration; GW, groundwater from Açu aquifer. 
of $\mathrm{K}$ fertilization has been suggested for sunflower plants grown under salt stress (Grieve \& Poss, 2010), but there are also relationships between nutrients that may affect the growth of sunflower plants, as shown by Sousa et al. (2016).

The concentrations of $\mathrm{Ca}, \mathrm{Fe}$, and $\mathrm{Zn}$ in the roots were positively affected by irrigation with PWO, during the second cycle (Table 6), in comparison to the treatment with PWF. It is worth noting that the treatments with PWO and GW had a very similar effect on the nutrition of sunflower plants (Tables 6 and 7), indicating the possibility of switching the traditional water source for irrigation by PWO. In addition, new technological options after wastewater treatment, ultrafiltration, nanofiltration, and reverse osmosis can be considered, as already pointed out by Munirasu et al. (2016). Possible ecological problems arising from the application of produced water in irrigation projects (Lopes et al., 2014) should be addressed to the oil industry. Regardless of the applied water types, there was a decrease of $\mathrm{Zn}$ content in shoots, and of the organic carbon accumulated in the plants during the second and third production cycles (Table 7), which may have been due to the increased competition for nutrients between ornamental sunflowers planted in a smaller spacing ( 3 plants in linear meter), compared to one plant in linear meter used during the first crop production cycle.

The operating result for the production of sunflower stems was estimated from the set of three successive production cycles. Given the agroclimatic conditions
Table 6. Content of nutrients accumulated in roots and stems of ornamental sunflower, as a result of irrigation treatments and plant production cycles ${ }^{(1)}$.

\begin{tabular}{|c|c|c|c|c|}
\hline Nutrient & Water type & Cycle 1 & Cycle 2 & Cycle 3 \\
\hline & \multicolumn{4}{|c|}{ Roots } \\
\hline \multirow{3}{*}{$\begin{array}{l}\mathrm{K} \text { - total } \\
\left(\mathrm{g} \mathrm{kg}^{-1}\right)\end{array}$} & PWO & $20.67 \mathrm{aA}$ & $8.77 \mathrm{bA}$ & $10.77 \mathrm{bB}$ \\
\hline & PWF & $9.10 \mathrm{bB}$ & $11.73 \mathrm{bA}$ & $17.13 \mathrm{aA}$ \\
\hline & GW & $9.83 \mathrm{aB}$ & $9.70 \mathrm{aA}$ & $6.41 \mathrm{aB}$ \\
\hline \multirow{3}{*}{$\begin{array}{l}\mathrm{Ca}-\text { total } \\
\left(\mathrm{g} \mathrm{kg}^{-1}\right)\end{array}$} & PWO & $3.33 \mathrm{bA}$ & $5.30 \mathrm{aA}$ & $2.07 \mathrm{cA}$ \\
\hline & PWF & $2.50 \mathrm{bA}$ & $4.10 \mathrm{aB}$ & $2.20 \mathrm{bA}$ \\
\hline & GW & $2.73 \mathrm{bA}$ & $4.60 \mathrm{aAB}$ & $2.80 \mathrm{bA}$ \\
\hline \multirow{3}{*}{$\begin{array}{l}\mathrm{Na} \text { - total } \\
\left(\mathrm{g} \mathrm{kg}^{-1}\right)\end{array}$} & PWO & $7.03 \mathrm{bC}$ & $10.07 \mathrm{bB}$ & $17.13 \mathrm{aB}$ \\
\hline & PWF & $26.47 \mathrm{aA}$ & $18.27 \mathrm{bA}$ & $27.87 \mathrm{aA}$ \\
\hline & GW & $13.90 \mathrm{bB}$ & $14.67 \mathrm{bA}$ & $24.30 \mathrm{aA}$ \\
\hline \multirow{3}{*}{$\begin{array}{l}\mathrm{Fe}-\text { total } \\
\left(\mathrm{mg} \mathrm{kg}^{-1}\right)\end{array}$} & PWO & $1,443.50 \mathrm{bA}$ & $3,151.40 \mathrm{aA}$ & $486.10 \mathrm{cA}$ \\
\hline & PWF & $847.00 \mathrm{bA}$ & $1,648.63 \mathrm{aB}$ & $616.33 \mathrm{bA}$ \\
\hline & GW & $1,265.73 \mathrm{bA}$ & $2,168.63 \mathrm{aB}$ & $478.20 \mathrm{bA}$ \\
\hline \multirow{3}{*}{$\begin{array}{l}\mathrm{Zn}-\text { total } \\
\left(\mathrm{g} \mathrm{kg}^{-1}\right)\end{array}$} & PWO & $35.47 \mathrm{aA}$ & $24.87 \mathrm{bA}$ & $14.07 \mathrm{cA}$ \\
\hline & PWF & $19.03 \mathrm{aB}$ & $12.83 \mathrm{abB}$ & $11.73 \mathrm{bA}$ \\
\hline & GW & $28.90 \mathrm{aA}$ & $21.77 \mathrm{bA}$ & $14.97 \mathrm{cA}$ \\
\hline & \multicolumn{4}{|c|}{ Stems } \\
\hline \multirow{3}{*}{$\begin{array}{l}\mathrm{K}-\text { total } \\
\left(\mathrm{g} \mathrm{kg}^{-1}\right)\end{array}$} & PWO & $31.57 \mathrm{aB}$ & $26.13 \mathrm{bA}$ & $19.40 \mathrm{bAB}$ \\
\hline & PWF & $39.17 \mathrm{aA}$ & $28.23 \mathrm{bA}$ & $24.43 \mathrm{bA}$ \\
\hline & $\mathrm{GW}$ & $27.20 \mathrm{aB}$ & $28.63 \mathrm{aA}$ & $18.03 \mathrm{cB}$ \\
\hline \multirow{3}{*}{$\begin{array}{l}\mathrm{Mg}-\text { total } \\
\left(\mathrm{g} \mathrm{kg}^{-1}\right)\end{array}$} & PWO & $1.07 \mathrm{bB}$ & $1.33 \mathrm{bA}$ & $2.13 \mathrm{aA}$ \\
\hline & PWF & $1.30 \mathrm{aAB}$ & $1.00 \mathrm{bB}$ & $1.17 \mathrm{abB}$ \\
\hline & GW & $1.37 \mathrm{bA}$ & $1.17 \mathrm{bAB}$ & $1.87 \mathrm{aA}$ \\
\hline \multirow{3}{*}{$\begin{array}{l}\mathrm{Na}-\text { total } \\
\left(\mathrm{g} \mathrm{kg}^{-1}\right)\end{array}$} & PWO & $0.60 \mathrm{aB}$ & $0.17 \mathrm{aB}$ & $1.40 \mathrm{aC}$ \\
\hline & PWF & $5.13 \mathrm{bA}$ & $2.83 \mathrm{cA}$ & $8.60 \mathrm{aA}$ \\
\hline & GW & $0.60 \mathrm{bB}$ & $0.40 \mathrm{bB}$ & $4.60 \mathrm{aB}$ \\
\hline
\end{tabular}

${ }^{(1)}$ Means followed by equal letters, lowercase in the lines, and uppercase in the columns, indicate no significant differences by the Tukey's test, at $5 \%$ probabilitye. Types of water: PWO, produced water treated by reverse osmosis; PWF, produced water treated by filtration; GW, groundwater from Açu aquifer.

Table 7. Concentration of nutrients accumulated in roots and shoots of ornamental sunflower, as a result of irrigation treatments and plant production cycles.

\begin{tabular}{|c|c|c|c|c|c|c|}
\hline \multirow[t]{2}{*}{ Nutrient } & \multicolumn{3}{|c|}{ Water type } & \multicolumn{3}{|c|}{ Production cycle } \\
\hline & PWO & PWF & GW & First & Second & Third \\
\hline & \multicolumn{6}{|c|}{ Roots } \\
\hline $\operatorname{COT}\left(\mathrm{g} \mathrm{kg}^{-1}\right)$ & $330.20 b$ & $353.40 \mathrm{a}$ & $366.60 \mathrm{a}$ & $385.20 \mathrm{a}$ & $324.80 \mathrm{~b}$ & $340.20 \mathrm{~b}$ \\
\hline $\mathrm{Mg}\left(\mathrm{g} \mathrm{kg}^{-1}\right)$ & $0.87 \mathrm{a}$ & $0.62 \mathrm{a}$ & $0.73 \mathrm{a}$ & $0.57 \mathrm{~b}$ & $0.88 \mathrm{ab}$ & $0.78 \mathrm{a}$ \\
\hline \multirow[t]{2}{*}{$\operatorname{Mn}\left(\mathrm{mg} \mathrm{kg}^{-1}\right)$} & $110.46 \mathrm{a}$ & $76.78 \mathrm{a}$ & $61.40 \mathrm{a}$ & $93.38 \mathrm{a}$ & $101.17 \mathrm{a}$ & $82.87 \mathrm{a}$ \\
\hline & \multicolumn{6}{|c|}{ Stems } \\
\hline $\operatorname{COT}\left(\mathrm{g} \mathrm{kg}^{-1}\right)$ & $448.20 \mathrm{a}$ & $441.80 \mathrm{a}$ & $458.60 \mathrm{a}$ & $663.60 \mathrm{a}$ & $335.20 \mathrm{~b}$ & $349.80 \mathrm{~b}$ \\
\hline $\mathrm{Ca}\left(\mathrm{g} \mathrm{kg}^{-1}\right)$ & $4.69 \mathrm{a}$ & $4.58 \mathrm{a}$ & $5.01 \mathrm{a}$ & $4.73 a$ & $5.59 \mathrm{a}$ & $3.96 \mathrm{a}$ \\
\hline $\mathrm{Fe}\left(\mathrm{mg} \mathrm{kg}^{-1}\right)$ & $65.91 \mathrm{a}$ & $69.78 \mathrm{a}$ & $61.40 \mathrm{a}$ & $104.92 \mathrm{a}$ & $30.03 \mathrm{c}$ & $62.13 b$ \\
\hline $\operatorname{Mn}\left(\mathrm{mg} \mathrm{kg}^{-1}\right)$ & $55.46 \mathrm{a}$ & $41.68 \mathrm{a}$ & $38.06 \mathrm{a}$ & $51.32 \mathrm{a}$ & $42.86 a$ & $41.01 \mathrm{a}$ \\
\hline $\mathrm{Zn}\left(\mathrm{mg} \mathrm{kg}^{-1}\right)$ & $17.20 \mathrm{a}$ & $14.48 \mathrm{a}$ & $18.03 \mathrm{a}$ & $22.98 \mathrm{a}$ & $13.28 \mathrm{~b}$ & $13.46 \mathrm{~b}$ \\
\hline
\end{tabular}

Types of water: PWO, produced water treated by reverse osmosis; PWF, produced water treated by filtration; GW, groundwater from Açu aquifer. Results followed by equal letters in the lines, for each factor, indicate no significant differences by the Tukey's test, at $5 \%$ probability. 
of the FZB and the necessary infrastructure for irrigation, three sunflower production cycles per year could easily be obtained. With these assumptions, the potential production of 90,000 stems $\mathrm{ha}^{-1}$ irrigated with PWO, and the total of 85,000 stems ha ${ }^{-1}$ irrigated with PWF or control water were estimated. However, by using reduced spacing between plants or rows, crop productivity can be increased. Khakwani et al. (2014) tested different plant densities and NPK dosages, and they observed an economic advantage by using 110,000 plants ha- ${ }^{-1}$, and $150 \mathrm{~kg} \mathrm{~N}, 120 \mathrm{~kg} \mathrm{P}$, and $100 \mathrm{~kg}$ $\mathrm{K} \mathrm{h}^{-1}$ fertilization.

In the present study, favorable economic operating results were obtained with all types of water used (Table 8) for the production of ornamental sunflower stems. The best result was obtained in plots receiving control groundwater, followed by treatment with PWF and PWO. The operating margins were equivalent to $86 \% \mathrm{GW}, 81 \%$ for PWF, and only $25 \%$ for treatment with PWO. As to this last result, there was a considerable impact on the process engineering costs, as a consequence of water treatment by reverse osmosis at the FZB wastewater treatment plant. The investment and process engineering costs for the treatment of wastewater in oilfields could be considered as critical points by the oil exploration industry. A political decision to reuse produced water would be desirable in the Brazilian Semiarid Region, as well as investments in the axis of the production and marketing of flowers and ornamental plants in the vicinity of the territorial oilfields.

The economic result of the use of PWF merits further research. In the short term, water changes

Table 8. Operating results in the production of flower stems (US\$ ha-1) of the ornamental sunflower hybrid F1 'Sunbright', under irrigation with different types of water at the Belém farm in Aracati, Ceará.

\begin{tabular}{lccc}
\hline Costs and & \multicolumn{3}{c}{ Irrigation treatments } \\
\cline { 2 - 4 } revenues & PWO & PWF & GW \\
\hline Operational costs & $78,108.24$ & $18,358.24$ & $14,108.24$ \\
Operational revenues & $104,166.67$ & $98,381.94$ & $98,381.94$ \\
Operational results & $26,058.43$ & $80,023.70$ & $84,273.70$ \\
Operational margin & 25.0 & 81.3 & 85.7 \\
Cost-benefit ratio & 33.36 & 435.90 & 597.34 \\
\hline
\end{tabular}

Types of water: PWO, produced water treated by reverse osmosis; PWF, produced water treated by filtration; GW, groundwater from Açu aquifer. Dollar exchange rate (US\$ $1.00=\mathrm{R} \$ 2.16$ ), based on the average value in 2012, according to Banco Central do Brasil (Relatório..., 2012). of the concentration of some salts in the soil were observed. However, irrigation with treated produced water needs to be better evaluated in the medium and long terms, taking into account the effects on soil degradation, aspects of mitigation of the salinization, and sodification processes, and the efficiency of nutrient absorption and growth of ornamental sunflower plants. Management strategies of brackish water and plants tolerant to salt stress are considered keys to the economic and environmental sustainability of the production system (Qadir \& Oster, 2004), and this can result in economic growth in agricultural regions where there is a seasonal shortage of fresh water.

\section{Conclusions}

1. Oilfield produced water - treated by simple filtration in sand-filled filters and cation exchange units, and used by drip irrigation of the ornamental sunflower 'Sunbright' (Helianthus annus) - modifies the concentration of exchangeable salts in the soil, increasing $\mathrm{Na}^{+}$in shallow layers, and affecting the vegetative growth and nutrient accumulation in the plants.

2. The application of produced water, filtered and treated by reverse osmosis, has a minor effect on the concentration of exchangeable nutrients in a Typic Quartzipsamment, and it is not able to modify the agronomic performance of ornamental sunflowers, in comparison to irrigation using groundwater from the Açu aquifer.

3. Cost-benefit ratios of the ornamental sunflower production systems are positive for the three types of water tested, varying in an ascending order with the use of the groundwater (GW), the produced water treated by simple filtration (PWF), and produced water treated by reverse osmosis (PWO).

\section{Acknowledgments}

To Petróleo Brasileiro S.A. (Petrobras), for financial support; and to project staff and to students, for support in activities and in field work, respectively.

\section{References}

ALLISON, P.D. Survival analysis using SAS: A practical guide. $2^{\text {nd }}$ ed. Cary: SAS Institute Inc., 2010. 327p. 
AMBROSANO, E.J.; TANAKA, R.T.; MASCARENHAS, H.A.A.; RAIJ, B. VAN; QUAGGIO, J.A.; CANTARELLA, H. Leguminosas e oleaginosas. In: RAIJ, B. van; CANTARELLA, H.; QUAGGIO, J.A.; FURLANI, A.M.C. (Ed.). Recomendações de adubação e calagem para o Estado de São Paulo. 2.ed. rev. e atual. Campinas: Instituto Agronômico, 1997. p.189-203. (IAC. Boletim técnico, 100).

ANP. Agência Nacional do Petróleo, Gás Natural e Biocombustíveis. Anuário estatístico brasileiro do petróleo, gás natural e biocombustíveis: 2016. 2016. Available at: <http://www.anp.gov. br/wwwanp/images/publicacoes/Anuario_Estatistico_ANP_2016. pdf>. Accessed on: Feb. 22017.

AYERS, R.S.; WESTCOT, D.W. Water Quality for Agriculture. rev. 1. Rome: FAO, 1985. 174p. (FAO Irrigation and Drainage Paper, 29).

BRESSIANI, D. de A.; GASSMAN, P.W.; FERNANDES, J.G.; GARBOSSA, L.H.P.; SRINIVASAN, R.; BONUMÁ, N.B.; MENDIONDO, E.M. Review of Soil and Water Assessment Tool (SWAT) applications in Brazil: challenges and prospects. International Journal of Agricultural and Biological Engineering, v.8, p.9-35, 2015.

CARRILLO-ÁVILA, E.; GARCÍA-ACEDO, C.; ARREOLAENRÍQUEZ, J.; LANDEROS-SÁNCHEZ, C.; OSNAYAGONZÁLEZ, M.L.; CASTILLO-AGUILAR, C. Evaluation of four sunflower hybrids (Helianthus annuus) under three irrigation regimes and two doses of fertilization on flower production. Journal of Agricultural Science, v.7, p.183-194, 2015. DOI: 10.5539/jas.v7n4p183.

CLAESSEN, M.E.C. (Org.). Manual de métodos de análise de solo. 2.ed. rev. e atual. Rio de Janeiro: EMBRAPA-CNPS, 1997. 247p. (EMBRAPA-CNPS. Documentos, 1).

CRISOSTOMO, L.A.; WEBER, O.B.; MIRANDA, F.R. de; ARAGÃO, F.A.S. de; OLIVEIRA, M.E.B. de. Irrigação com água produzida: efeitos sobre características do solo e a produção do girassol. Fortaleza: Embrapa Agroindústria Tropical, 2016. 35p. Available at: <https://www.infoteca.cnptia.embrapa.br/ infoteca/bitstream/doc/1053776/1/BPD16012.pdf $>$. Accessed on: Oct. 102016.

CURTI, G.L.; MARTIN, T.N.; FERRONATO, M. de L.; BENIN, G. Girassol ornamental: caracterização, pós-colheita e escala de senescência. Revista de Ciências Agrárias, v.35, p.240-250, 2012.

EATON, A.D.; FRANSON, M.A.H. (Ed.). Standard methods for the examination of water and wastewater. $21^{\text {st }}$ ed. Washington: American Public Health Association, 2005.

FRANCOIS, L.E. Salinity effects on four sunflower hybrids. Agronomy Journal, v.88, p.215-219, 1996. DOI: 10.2134/agronj 1996.00021962008800020016x.

GRIEVE, C.M.; POSS, J.A. Response of ornamental sunflower cultivars 'Sunbeam' and 'Moonbright' to irrigation with saline wastewaters. Journal of Plant Nutrition, v.33, p.1579-1592, 2010. DOI: $10.1080 / 01904167.2010 .496883$.

IGUNNU, E.T.; CHEN, G.Z. Produced water treatment technologies. International Journal of Low-Carbon Technologies, v.9, p.157-177, 2014. DOI: 10.1093/ijlct/cts049.
JUNQUEIRA, A.H.; PEETZ, M. da S. O setor produtivo de flores e plantas ornamentais do Brasil, no período de 2008 a 2013: atualizações, balanços e perspectivas. Revista Brasileira de Horticultura Ornamental, v.20, p.115-120, 2014. DOI: 10.14295/ rbho.v20i2.727.

KHAKWANI, A.A.; NOOR, S.; SADIQ M.; AVAN, I.U.; MUNIR, M.; BALOCH, M.S.; GHANSFARULLAH; BAKHSH, I. Impact of plant densities and NPK fertilization on growth and optimum economic return of sunflower. Sarhad Journal of Agriculture, v.30, p.157-164, 2014.

LOPES, E.D.O.R.; WEBER, O.B.; CRISÓSTOMO, L.A.; MATTOS, E.P.N.B. de. Short-term effects of produced water on microbial activity in semiarid soil. International Journal of Current Microbiology and Applied Sciences, v.3, 395-403, 2014.

MACIEL, M.P.; SOARES, T.M.; GHEYI, H.R.; REZENDE, E.P.L.; OLIVEIRA, G.X.S. Produção de girassol ornamental com uso de águas salobras em sistema hidropônico NFT. Revista Brasileira de Engenharia Agrícola e Ambiental, v.16, p.165172, 2012. DOI: $10.1590 /$ S1415-43662012000200006.

MELO, E.E.C. de; NASCIMENTO, C.W.A. do; SANTOS, A.C.Q. Solubilidade, fracionamento e fitoextração de metais pesados após aplicação de agentes quelantes. Revista Brasileira de Ciência do Solo, v.30, p.1051-1060, 2006. DOI: 10.1590/S010006832006000600014.

MELO, J.G. de; MEDEIROS, A.B. de; VASCONCELOS, M.B.; CASTRO, V.L.L. de. Aspectos hidrogeoquímicos e classes de água do aquífero cárstico Jandaíra para irrigação, Baraúna, RN. Águas Subterrâneas, v.21, p.9-21, 2007.

MELO, M.; SCHLÜTER, H.; FERREIRA, J.; MAGDA, R.; JÚNIOR, A.; AQUINO, O. de. Advanced performance evaluation of a reverse osmosis treatment for oilfield produced water aiming reuse. Desalination, v.250, p.1016-1018, 2010. DOI: 10.1016/j. desal.2009.09.095.

MUNIRASU, S.; ABU HAIJA, M.; BANAT, F. Use of membrane technology for oil field and refinery produced water treatment - a review. Process Safety and Environmental Protection, v.100, p.183-202, 2016. DOI: 10.1016/j.psep.2016.01.010.

OLIVEIRA, A.C.de; CRUZ, R.L.; BISCARO, G.A.; MOTOMIYA, A.V. de A.; FREIRE, M. Use of ferrous water for drip irrigation of ornamental sunflower in pots. Irriga, v.19, p.245-254, 2014. DOI: 10.15809/irriga.2014v19n2p245.

OLIVEIRA, P.C.P. de; GLOAGUEN, T.V.; GONÇALVES, R.A.B.; SANTOS, D.L.; COUTO, C.F. Soil chemistry after irrigation with treated wastewater in semiarid climate. Revista Brasileira de Ciência do Solo, v.40, p.1-13, 2016. DOI: 10.1590/18069657rbcs20140664.

PEREIRA, G.R.; CUELLAR, M.D.Z. Conflitos pela água em tempos de seca no Baixo Jaguaribe, Estado do Ceará. Estudos Avançados, v.29, p.115-137, 2015. DOI: 10.1590/S010340142015000200008.

QADIR, M.; OSTER, J.D. Crop and irrigation management strategies for saline-sodic soils and waters aimed at environmentally sustainable agriculture. Science of the Total Environment, v.323, p.1-19, 2004. DOI: 10.1016/j.scitotenv.2003.10.012. 
RELATÓRIO ANUAL 2012. Boletim do Banco Central do Brasil, v.48, 2012. Available at: <http://www.bcb.gov.br/pec/ boletim/banual2012/rel2012p.pdf>. Accessed on: Mar. 232017.

RICHARDS, L.A. (Ed.). Diagnosis and improvement of saline and alkali soils. Washington: USDA, 1954. 160p. (USDA. Agriculture Handbook, 60).

SANCHEZ, P.A.; PALM, C.A.: BUOL, S.W. Fertility capability soil classification: a tool to help assess soil quality in the tropics. Geoderma, v.114, p.157-185, 2003. DOI: 10.1016/S00167061(03)00040-5.

SIEBERT, S.; BURKE, J.; FAUERS, J.M.; FRENKEN, K.; HOOGEVEEN, J.; DÖLL, P.; PORTMANN, F.T. Groundwater use for irrigation - a global inventory. Hydrology and Earth System Sciences, v.14, p.1863-1880, 2010. DOI: 10.5194/hess-141863-2010.

SILVA, F.C. da. Manual de análises químicas de solos, plantas e fertilizantes. 2.ed. rev. e ampl. Brasília: Embrapa, 2009. 627p.

SILVA, L.C. e; PAIVA, P.D. de O.; SANTOS, A.C. Flower and ornamental plants wholesale markets in Brazil. Ornamental Horticulture, v.21, p.53-62, 2015. DOI: 10.14295/rbho.v21i1.776.

SOUSA, A.F.; CRISÓSTOMO, L.A.; WEBER, O.B.; ESCOBAR, M.E.O.; OLIVEIRA, T.S. de. Nutrient content in sunflower irrigated with produced water. Revista Caatinga, v.29, p.94-100, 2016. DOI: 10.1590/1983-21252016v29n111rc.

Received on October 28, 2016 and accepted on February 23, 2017 